\title{
A Study on the Integration and Development of Excellent Traditional Chinese Culture and China's Ideological and Political Education in the New Era
}

\author{
Yuchun Liu* \\ Inner Mongolia Normal University Office of Students' Affairs Hohhot, Inner Mongolia 010022 \\ *Corresponding author. Email: 15450815@qq.com
}

\begin{abstract}
In the new era, it is of great significance to integrate excellent traditional Chinese culture with ideological and political education. For the country and society, such integration is conducive to the unity of different ethnical groups and national reunification, promoting the national spirit and building our spiritual home, and it is also beneficial for developing the socialist market economy, building a harmonious society and world. For schools, it can help to build the campus culture, enhance the timeliness of ideological and political education and improve schools' management level. For individuals, it can help students build their knowledge structure, cultivate their excellent ideological morality and behaviors, develop and practice the core values of socialism and enhance students' cultural consciousness and cultural confidence. This paper aims to promote the integrated development of excellent traditional Chinese culture and ideological and political education through "three integrations", i.e., to integrate theories with practice, with integrate online resources with offline resources and to integrate various powers from the school and families, thus providing reference and inspiration for ideological and political education.

Keywords: Excellent traditional culture of China, ideological and political education, integration
\end{abstract}

\section{INTRODUCTION}

In 2014, the ministry of education issued the guidance outline on improving the education of excellent traditional Chinese culture, and in January 2017, the general office of the CPC central committee and the general office of the state council issued the opinions on the implementation of the project for the inheritance and development of excellent traditional Chinese culture, which pointed out the direction for the development of excellent traditional Chinese culture education, and also pushed the education of excellent traditional Chinese culture to a new level. In the new era, ideological and political education plays an important role in the process of talent cultivation in schools. However, in ideological and political education, the integration of excellent traditional Chinese culture is conducive to the enhancement of socialist cultural strength with Chinese characteristics and the realization of the Chinese dream of national rejuvenation. In this regard, the author analyzes and explores the theme of the fusion development of Chinese excellent traditional culture and ideological and political education, and tries to explore a feasible path to inspire the ideological and political educators.

\section{THE SIGNIFICANCE OF CARRYING FORWARD THE FINE TRADITIONAL CHINESE CULTURE IN IDEOLOGICAL AND POLITICAL EDUCATION}

\subsection{For the Country and Society, It Is Conducive to the Realization of the Chinese Dream of the Great Renewal of the Chinese Nation}

\subsubsection{It is conducive to national unity and national unity}

Safeguarding national unity and national unity is an important part of the patriotic tradition of the Chinese nation and a cornerstone for the Chinese nation to live in harmony and forge ahead together. This kind of value pursuit is not only the common cultural psychology and value orientation of the Chinese nation, but also the spiritual pillar of the Chinese nation. In the new era, carrying forward this spirit is of great significance for strengthening ethnic integration, promoting ethnic unity, consolidating and developing socialist harmonious ethnic relations and promoting national unity. 


\subsubsection{It is conducive to carrying forward the Chinese spirit and building a spiritual home together}

Chinese spirit is the driving force of Chinese national unity and the power source of realizing the great revival of Chinese nation, mainly including patriotic, gratitude, hard-working, and mutual assistance, open and enterprising, innovative, inclusive, thick Germany, modest, pragmatic, forge ahead, good faith, compatibility, studious, mutual trust, mutual benefit, consultation, respect, love, morality, equality, peace, such as Chinese spirit connotation is rich and profound. It is the spiritual core of the fine traditional Chinese culture, the moral code of the socialist market economy with Chinese characteristics and the spiritual civilization, and the spiritual support for the survival and development of the Chinese nation. In the new era, the integration of fine traditional Chinese culture and ideological and political education will not only promote the Chinese spirit and build a spiritual home together, but also promote national pride and contribute to the construction of the socialist core value system.

\subsubsection{It is conducive to the development of the socialist market economy}

Credit is a basic principle of market economy, which requires people to trade in a fair and reasonable principle, which is also a necessary condition for the healthy and orderly development of socialist market economy. In the new era, the ideological and political education, promote the "love baiban (" Chinese excellent traditional culture," modest gifts ", "the good faith know newspaper", "self-denial devotion", "repair oneself self-supervision", "see leith righteousness", "diligence and integrity", "honest generous", "yong perseverance" traditional virtues, such as help build orderly market economy. Socialist market economy is by no means a simple and purely economic market. It must be guided by culture and have a cultural atmosphere. China's fine traditional culture is an important spiritual pillar of China's socialist market culture and plays a normative role in the development of the socialist market economy. Correctly guiding people to contact and understand China's excellent traditional culture can have a positive impact on people's ideology, value concept and behavior, thus conducive to the healthy and orderly development of the market economy.

\subsubsection{Conducive to the construction of a harmonious society and a harmonious world}

There is a rich culture of "harmony" in Chinese traditional culture. "harmony" is not only the common ideal and aspiration of people of all ethnic groups in the world, but also the essence and essence of Chinese excellent traditional culture. The thought of "harmony" has laid a solid theoretical foundation and theoretical source for the construction of harmonious culture in the new era of our country. Therefore, in the new era, in the ideological and political education, carry forward the excellent traditional Chinese culture of "harmony" culture, for the construction of a harmonious society, a harmonious world has a major role in promoting.

\subsection{For the School, Conducive to the Construction of the School}

\subsubsection{It is conducive to the cultural construction of the campus}

The ideological and political education in the school mainly includes the classroom teaching of ideological and political theory, the practical teaching of ideological and political theory education and the ideological and political education. New era, the Chinese excellent traditional culture and ideological and political education, not only can provide the ideological and political theory teaching with colorful living education teaching resources, from Chinese excellent traditional culture can also find some suitable education methods, the transformation of the mode of ideological and political teaching, can also with Chinese excellent traditional festivals as an opportunity to organize some meaningful activities, at the same time can also be injected into the school of Chinese excellent traditional culture elements in the construction of the campus, which will be conducive to the construction of campus culture.

\subsubsection{It is conducive to enhancing the effectiveness of ideological and political education}

In the process of talent cultivation, ideological and political education plays a particularly important role. It aims to help students establish a scientific outlook on life, values and money view, improve their political quality and improve their marxist quality through the study of ideological and political education. As the soul of the Chinese nation, excellent traditional Chinese culture embodies the wisdom and spirit of the ancient Chinese people. In the new era, the integration of excellent traditional Chinese culture and ideological and political education, so as to find the inherent convergence of the two, can not only enrich the resources of ideological and political education, but also enrich the teaching methods of ideological and political theory courses. All these will help to improve the comprehensive level of ideological and political education, so as to enhance the effectiveness of ideological and political education.

\subsubsection{It is conducive to improving the management level of the school}


New era, ideological and political education in the Chinese excellent traditional culture and the development of integration, the Chinese excellent traditional culture of some of the ideas, such as the national interests than personal thoughts, ideal personality view of education, the unity of nature and harmonious ideas throughout the school ideological and political education, lets the student by the edification of the Chinese excellent traditional culture, for students to build a harmonious interpersonal relationship is very important for the inter-school relations, harmony, thus is advantageous to the school's management level, is conducive to the construction of harmonious campus.

\subsection{For Individuals, It Is Conducive to the Overall Development of Students}

\subsubsection{It is conducive to the construction of students' knowledge structure}

New era, Chinese excellent traditional culture, whether in elementary school, junior high school, high school or university, there are marginalized, empty the phenomenon of generalization and label, "aphasia" in some disciplines, teaching material of "missing", "the voice" on the BBS, [1] lead to the lack of scientific system of Chinese traditional culture, this also caused the student of Chinese excellent traditional culture knowledge reserves is insufficient, the phenomenon of lack of bottom spirit. However, the Chinese excellent traditional culture into the ideological and political education of the students, make up for the deficiency of the students' knowledge of Chinese excellent traditional culture, also makes the theory of our party and the Chinese excellent traditional culture inheritance, makes the student receives the wisdom and strength of Chinese excellent traditional culture, also improved the students' knowledge structure, has profound significance for improving the students' humanities cultivated manners.

\subsubsection{It is conducive to cultivating students' good ideological and moral character and behavior habits}

The aim of ideological and political education is to train qualified builders and successors of the cause of socialism with Chinese characteristics. China's fine traditional culture has always pursued the courage to explore, perseverance, innovation and pioneering spirit of struggle, ambition, the practice of overcoming the spirit of self, the patriotic spirit of taking the world as its own responsibility, the pursuit of truth, the spirit of dedication and the ethical ethics of virtue. In the new era, these excellent traditional culture will run through the process of ideological and political education, which will help to cultivate students' good ideological and moral character and behavior habits, and help students to establish correct values, outlook on life and money view.

\subsubsection{It is conducive to cultivating and practicing socialist core values among students}

School is an important field to train the successors of socialism in the new era and to cultivate and practice the core values of socialism. In the new era, excellent traditional Chinese culture will be integrated into the ideological and political education of students in the new era, and the ideological and political education of excellent traditional Chinese culture will be deeply explored. To guide students to establish a harmonious social relationship with the principle of "one's desire is to establish others, one's desire is to achieve success"; With the personality cultivation of "words must be honest and actions must be upright", students can be promoted to form a good moral cultivation, so that students can have a deep understanding of the ideological character and moral standards contained in the fine traditional Chinese culture in the ideological and political education, so as to help students correctly understand and grasp the socialist core values in the new era. Once the socialist dominant values become the mainstream values universally accepted and widely recognized by students, it is beneficial for students to consciously practice the socialist core values and actively build the socialist advanced culture.

\subsubsection{It is conducive to enhancing students' cultural awareness and cultural confidence}

The fine traditional Chinese culture, stretching for thousands of years, has rich connotations. Ancient China not only left us rich philosophical thoughts, but also left us many traditional virtues; Not only left us many brilliant literary achievements, but also left us many traditional folk culture. In addition, there are many famous historical and cultural sites (such as the Palace Museum, the Great Wall, terra-cotta warriors and horses, etc.) as well as the four great ancient inventions which are worthy of our pride and pride, which are the contributions of the Chinese nation to mankind. As a result, a new era in the ideological and political education, to carry forward Chinese excellent traditional culture, the Chinese excellent traditional culture and ideological and political education effective fusion, students can not only wake up new era of the traditional culture gene, greatly enhanced the student to the identity of the Chinese excellent traditional culture, promote its cultural self-esteem consciousness of confidence, more can give youth the spirit of the modern students, effective against foreign culture shock and western ideology, to ensure Chinese cultural security, build a security fence ideology. [2] in addition, by interpreting from the perspective of traditional Chinese culture, students will understand why our party chose the path of socialism with Chinese characteristics, which has great persuasiveness 
and great power of truth, and enhances students' cultural confidence and theoretical consciousness. [3]

\section{THE USE OF "THREE INTEGRATION" TO PROMOTE THE INTEGRATION AND INNOVATIVE DEVELOPMENT OF EXCELLENT TRADITIONAL CHINESE CULTURE AND IDEOLOGICAL AND POLITICAL EDUCATION}

\subsection{Combination of Theory and Practice}

\subsubsection{Integration of excellent traditional Chinese culture and ideological and political theory classroom teaching}

First, in the ideological and political theory textbooks, it is necessary to timely launch the research, demonstration, pilot exploration and promotion evaluation of the curriculum standard revision and curriculum development integrated with the excellent traditional Chinese culture, and integrate the teaching links with the relevant contents of the excellent traditional Chinese culture. In addition, schools in each region should fully explore and make use of local excellent traditional cultural and educational resources. [4] secondly, the textbooks related to ideological and political theories should be revised to integrate the excellent traditional Chinese culture into them, and the multimedia network teaching resources with rich contents, active forms and popularity should also be made. In mature areas, excellent traditional Chinese cultural textbooks with regional culture can be compiled and included in students' quality-oriented education as a general education course. Once again, we need to change the pattern of ideological and political theory course teaching, research type, theme, participatory, and other popular with the students the way of teaching, full use of various media, online research, discussion and debate, a variety of activities, such as analog actively expand the ideological and political theory teaching effective form of omni-directional three-dimensional multiple perspectives, to promote Chinese excellent traditional culture and ideological and political theory teaching.

\subsubsection{Integration of Chinese excellent traditional culture and ideological and political theory practice teaching}

In the new era, the classroom teaching of the school can no longer meet the requirements of students' quality training, so the educators need to actively expand various forms of practical teaching. Ideological and political education in the Chinese excellent traditional culture and fusion process, teachers can according to the curriculum and training talents needs to guide students to take an active part in social practice activities, such as tissue around the students to experience the local conditions and customs, folk style, can also go to visit famous mountains around the water, places of interest, can also go to visit museums, memorial halls, law UK folk museum, science museum, you can also go to visit all sorts of patriotism education bases, it can enrich the student's field of vision, to make the students feel the charm of Chinese excellent traditional culture in practice.

\subsection{Combination of Online and Offline Resources}

\subsubsection{Importance should be attached to the role of "online" resources in the integrated development of excellent traditional Chinese culture and ideological and political education "Online" refers to the integrated development of excellent traditional Chinese culture and ideological and political education in the era of "Internet plus" by means of new media and other media.}

For example, the school can establish a website with the theme of excellent traditional Chinese culture to publicize the excellent traditional Chinese culture or local excellent traditional culture, so that its unique thought essence, inspiration and candle shine on the students. In addition, We Chat platform, microblog or network teaching platform can also be used to establish teaching resources integrating video, audio, animation and text, so as to achieve all-round three-dimensional and multi-angle coverage and meet the cultural needs of students in new media.

\subsubsection{Importance should be attached to the role of "offline" resources in the integrated development of excellent traditional Chinese culture and ideological and political education}

"Offline" refers to media other than new media, mainly including traditional media, such as books, materials, newspapers and magazines. In the new era, the existing books and materials in schools in various stages of our country are far from meeting the needs of students to learn the excellent traditional Chinese culture. Therefore, the organic integration of Chinese excellent traditional culture and ideological and political education requires increasing the number of books in this field, improving the reading quality of books in this field, and exerting the cultural influence of traditional media on students' ideological and political education. 


\subsection{The Combination of Social, School and Family Forces}

In the new era, the integration of fine traditional Chinese culture and ideological and political education requires not only the active role of schools as the main channel, but also the joint efforts of the society and the family.

\subsubsection{The society should provide institutional guarantee and create cultural atmosphere for the integration of excellent traditional Chinese culture and ideological and political education}

First of all, the social various departments to establish a scientific management system, from top to bottom, to develop a detailed Chinese excellent traditional culture propaganda way, encourage the whole society attaches great importance to the dissemination and promotion of Chinese excellent traditional culture, attaches great importance to the positive influence in the field of culture in social morality, especially students, as future builders and successors of the motherland, more should continue to strengthen the Chinese excellent traditional culture education. Actively promote and guide the fine traditional Chinese culture education into the campus. At the same time, the school's traditional culture education implementation plan including curriculum construction, teacher training, teaching research, books and materials construction, policy supporting, evaluation system construction and other contents is formulated to ensure the solid progress of this work. [5] secondly, in urban and rural construction, in the construction of streets, as well as in the propaganda of radio, television and other news media, we should inject excellent traditional Chinese cultural elements, so as to make them play a positive role in people's moral construction, create a cultural atmosphere, and achieve the purpose of educating people with culture and culture.

\subsubsection{The school should take various measures to promote the integration of excellent traditional Chinese culture and ideological and political education}

First, schools should strengthen the construction of campus culture. Campus culture is an important part of school ideological and political education, which plays a silent role in the cultivation of students. It is an important guarantee for the success of the campus culture to integrate the excellent traditional Chinese culture into the campus culture. Schools can enhance the connotation of excellent traditional Chinese culture in terms of infrastructure construction on campus, such as integrating excellent traditional Chinese culture into libraries, teaching buildings, dormitories and propaganda boards on campus. Schools can also to the Chinese traditional festivals as an opportunity, a wide range of some activities, such as speech contest, debate, photography contest, knowledge competition, culture, reading, chess contest, calligraphy contest and traditional cultural art, etc., can also employ some experts or famous people to carry out the lecture or discussion, let the students close communication and exchanges with them, and they also can lead the students to visit the region of the museum, science museum, law UK folk museum and cultural monuments, experience the bright of the Chinese excellent traditional culture.

Secondly, the school should strengthen the theoretical research on the integration development of Chinese excellent traditional culture and ideological and political education. As a theoretical innovation and theoretical support for the integrated development of Chinese fine traditional culture and ideological and political education, theoretical research is very important. To enhance the integration and development of fine traditional Chinese culture and ideological and political education to a high level. Chinese excellent traditional culture and the integration of ideological and political education development, the new era is to deepen the education of socialism with Chinese characteristics and the Chinese dream power important way of education, and cultivate and practice the socialist core values, the implementation of the important basis of khalid ents basic task, related to the direction of the school ideological and political education, also the direction of the school personnel training. Therefore, we should attach importance to the integration of Chinese fine traditional culture and ideological and political education. In addition, it is necessary to strengthen the research on the breadth and depth of the integration of Chinese fine traditional culture and ideological and political education. At present, the theoretical research on the integrated development of excellent traditional Chinese culture and ideological and political education is still in its early stage, lacking a systematic scientific system and the depth and breadth of research, so it needs to be further strengthened. It is necessary to strengthen the theoretical innovation research on the integration development of Chinese fine traditional culture and ideological and political education. In order to provide theoretical support for the practice of the fusion development of Chinese excellent traditional culture and ideological and political education, it is necessary to find innovative points in the content and methods of the fusion. Third, to improve the traditional cultural literacy of teachers. In school, have a combination of marxist theory of ideological and political teachers and one of the few Chinese excellent traditional culture accomplishment, so need through various channels, such as training, visit, investigation and discussion, etc.) continuous effective Chinese excellent traditional culture of thought political teacher education training, make the ideological and political teachers can effectively put the ideological and political education and the Chinese excellent traditional culture organic integration. Ideological and political workers should also pay attention to their own cultural literacy, pay attention to their behavior, in order to play an example in front of the students. In addition, as an educator 
to actively guide students to read more books, read good books, with the excellent traditional Chinese culture, establish a positive attitude, efforts to improve their own cultural accomplishment.

\subsubsection{Attach importance to the role of family in the integration of fine traditional Chinese culture and ideological and political education}

In 2014, the ministry of education promulgated "the perfect Chinese excellent traditional culture education guidance outline of pointed out:" give full play to the important role of family, "the parents asked:" advocates parents by precept, and form a patriotic law-abiding, abide by social morality, cherish affection, thrifty, good family trait of their neighbors, to carry forward Chinese excellent traditional culture of family education atmosphere ". [6] give full play to the role of families in carrying forward the fine traditional Chinese culture. Therefore, as parents, we should strive to enhance their own cultural literacy, moral literacy, to provide important support for students to learn excellent traditional Chinese culture.

Parents are the children's first teachers. The family education of students is of vital importance and is an important carrier of cultural inheritance. The traditional ideas of respecting the old and cherishing the young, being industrious and thrifty, as well as the cultivation of reading habits, living habits, eating habits and other habits, are taught by family through words and deeds. The school can timely communicate with parents through WeChat group, QQ group, school information, etc., or through the community, units, etc., parents can be invited to learn Chinese excellent traditional culture, to make every effort to promote and carry forward the excellent traditional Chinese culture of family education atmosphere.

In short, in the new era, we should integrate the excellent traditional Chinese culture into the ideological and political education, give play to the leading role of the excellent traditional Chinese culture, and infiltrate the excellent traditional Chinese culture into all aspects of the ideological and political education of students, so that its connotation can be sublimated in the ideological and political education of students. Let the political function of ideological and political education complement the cultural background of excellent traditional Chinese culture, and influence and inspire students.

\section{ACKNOWLDEGMENT}

Fund project: the research project of the 13th five-year plan of the education science of Inner Mongolia autonomous region "the research on the integration and development of excellent traditional Chinese culture and ideological and political education of college students in the new era" (project no. NGJGH2019270)

\section{REFERENCES}

[1] Ma Zhongquan. Research on the support system of integrating excellent traditional culture into Ideological and political education of college students [J]. Social Sciences, 2017 (11) P159. P160.

[2] Fan Haiyuan. Innovation of Ideological and political theory course construction and education mode [J]. Research on Ideological and Political Education, 2015(12). P61.

[3] Xi Jinping. Ministry of education. Improve the teaching guidelines for Chinese excellent traditional culture. [Z]

http://www.gov.cn/xinwen/2014-04/01/content_265115 4.htm.2014-3-26.

[4] Liu Shuxia. The real and ought to be state of the integration of Chinese traditional culture and ideological and political education in Colleges and universities. Tangdu journal. 2011(1). P96. 